\title{
No Evidence of Germline Mutation or Somatic Deletion of the MEN1 Gene in a Case of Familial Multiple Endocrine Neoplasia Type 1 (MEN1)
}

\author{
Hiroyoshi NAMIHIRA, Makoto SATO, Shuji MATSUBARA, Hidemi OHYE, MMR BHUIYAN, \\ KOJI MURAO AND JIRO TAKAHARA
}

First Department of Internal Medicine, Kagawa Medical University, 1750-1 Ikenobe, Miki-cho, Kita-gun, Kagawa 761-0793, Japan

\begin{abstract}
The MENI gene has recently been cloned as the gene responsible for multiple endocrine neoplasia type 1 (MEN1) and its germline mutations have been identified in a number of familial MEN1 patients. However, mutation-negative cases have also been reported in some MEN1 families. We report here a Japanese MEN1 family, including a proband with no evidence of $M E N 1$ gene mutation. The proband (51 y.o., female) had three major MEN1 lesions, including primary hyperparathyroidism (HP), prolactinoma, and pancreatic tumor. Her father and brother had HP, and her daughter had both HP and prolactinoma. When we analyzed the proband for a germline mutation of the MENI gene, the direct sequencing analysis showed no mutation in the coding region, on the promoter, $5^{\prime}$ and $3^{\prime}$ untranslated regions of the MENI gene. We next examined the loss of heterozygosity (LOH) in the proband's parathyroid tumors using two benign polymorphisms (C2249G in intron 1 and 2248del3 in exon 10) in the MEN1 gene to detect $\mathrm{LOH}$. LOH was not found in any of the four separate regions of the tumor tissues.
\end{abstract}

Keywords: MEN1, Mutation, Familial

(Endocrine Journal 46: 811-816, 1999)

FAMILIAL multiple endocrine neoplasia type 1 (MEN1) is an autosomal dominant disorder, the classical spectrum of which includes primary hyperparathyroidism (HP), tumors of the anterior pituitary and endocrine pancreas [1]. Less frequently observed associations include a foregut carcinoid, lipoma, thyroid diseases, and adrenal tumors. The gene responsible for MEN1 has been mapped to chromosome 11q13, and has frequently demonstrated loss of heterozygosity $(\mathrm{LOH})$ in the tumors of MEN1 patients [2,3]. Recently, the MENI gene was cloned [4] and a variety of mutations (more than 80 ) have been reported in the MENI gene to date [5-11]. The mutations include deletions, nonsense mutations, in-

Received: May 21, 1999

Accepted: October 6, 1999

Correspondence to: Makoto SATO, M.D., First Department of Internal Medicine, Kagawa Medical University, 1750-1, Ikenobe, Miki-cho, Kita-gun, Kagawa 761-0793, Japan sertions, missense mutations, deletional insertion, and donor splice-site mutations, of which the deletions are the most common mutations. They are scattered throughout the entire coding region of the $M E N 1$ gene, from exon 2 to 10, depending on the length of each exon. Exons 2 and 3 are the most common regions for the appearance of mutations, probably due to their large size, but this does not imply the true "hot spot" as reported in the RET gene of MEN2 [12]. On the other hand, no mutations of the $M E N 1$ gene are detected in some familial MEN1 patients $[5,10,11]$. In such cases, it is possible that mutations in the promoter and $5^{\prime}$ or $3^{\prime}$ untranslated regions of the $M E N 1$ gene are present. In this study, we analyzed the proband of a MEN1 family for germline mutations in the coding region, on the promoter, $5^{\prime}$ and $3^{\prime}$ untranslated regions of the MEN1 gene. Furthermore, LOH was examined in the parathyroid tumors taken from the proband. 


\section{Subjects and methods}

\section{Case Reports}

The pedigree of this family is shown in Fig. 1. The proband (S1, 51 y.o.) was diagnosed as having primary hyperparathyroidism (HP) at age 47 and subsequently underwent total parathyroidectomy at Kagawa Medical University Hospital. The pathological diagnosis was hyperplasia of four parathyroid glands. She had a high level of serum prolactin $(300.0 \mathrm{ng} / \mathrm{ml})$, and cranial magnetic resonance imaging (MRI) revealed a pituitary tumor (Fig. 2A). Since there was no other causes (e.g. history of medication) to increase serum prolactin, her pituitary tumor was clinically diagnosed as prolactinoma. She was treated with bromocriptine (BRC) and her serum prolactin levels rapidly decreased. Abdominal computed tomography (CT) showed a pancreatic tumor (Fig. 2B) and her serum gastrin levels were very high $(310 \mathrm{ng} / \mathrm{ml})$. Surgical treatment was not chosen due to renal failure (creatinine levels $3-4 \mathrm{mg} / \mathrm{dl}$ ) which occurred after parathyroidectomy. She also had a gastric carcinoid. Her brother (S2, 48 y.o.) visited our hospital for family screening and was diagnosed as having $\mathrm{HP}$ at age 45 . His prolactin and gastrin levels were normal. He refused to undergo surgery for HP. The proband's younger daughter (S3, 24 y.o.) also visited our hospital for family screening and was diagnosed as having HP. Cranial MRI revealed a pituitary tumor (Fig. 2C) associated with a high level of serum prolactin (serum prolactin $110.0 \mathrm{ng} / \mathrm{ml}$ ). She was treated with BRC and her serum prolactin levels decreased to normal level. The proband's father ( $\mathrm{S} 4,89$ y.o.) was diagnosed as having HP by chance when he visited a local hospital. He had no examination for other MEN1-related lesions. Thus, in this family, there are at least four MEN1 patients.

\section{Mutation Analysis of the MEN1 Gene by Direct Sequencing}

Genomic DNA was isolated from peripheral blood samples from the proband after securing informed consent. The MEN1 gene exons 2-10, including the corresponding splice junction regions, were amplified by polymerase chain reaction (PCR), as previously described [11]. Four different pairs of primers (P1P2, P3-P4, P5-P6, P7-P8) were used as shown in Fig. 3. The $5^{\prime}$ and $3^{\prime}$ untranslated regions were am-

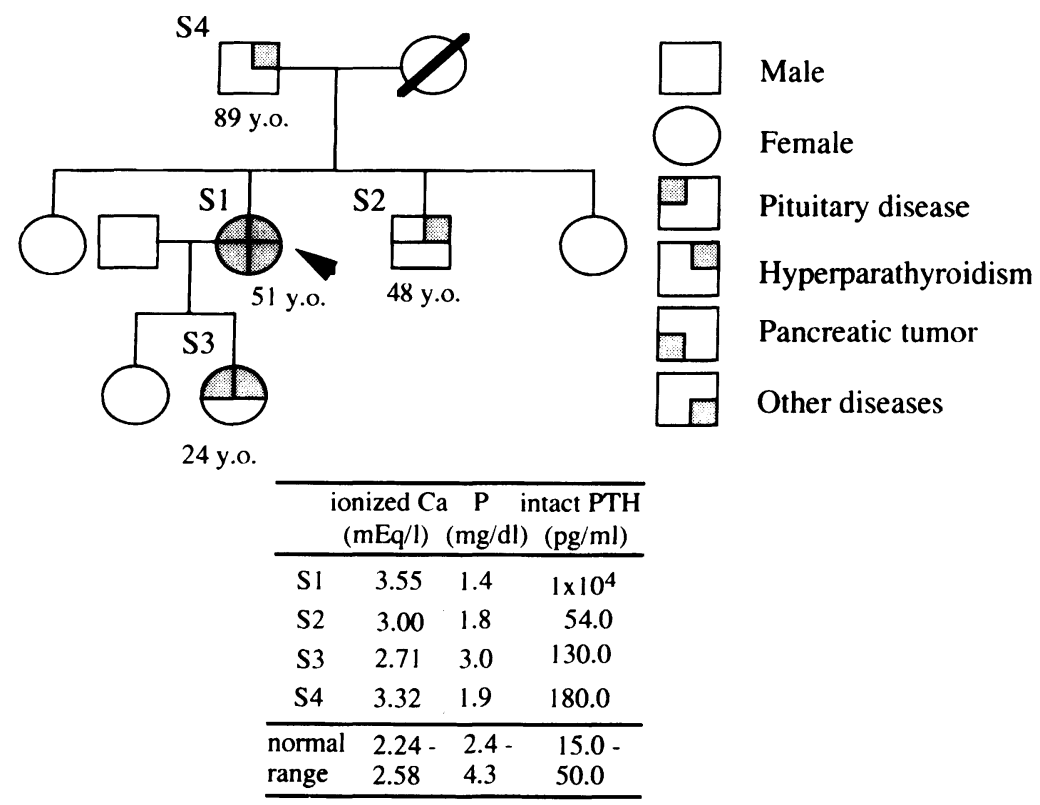

Fig. 1. Pedigree and phenotypes of this MEN1 family. The proband who undertook genetic analysis is indicated with an arrow. Subjects having MEN1 are shown as S1, S2, S3, and S4. Other family members had no examination on MEN1-related lesions. Serum levels of ionized calcium $(\mathrm{Ca})$, phosphate $(\mathrm{P})$, and intact PTH are shown in the table superimposed on the table. 

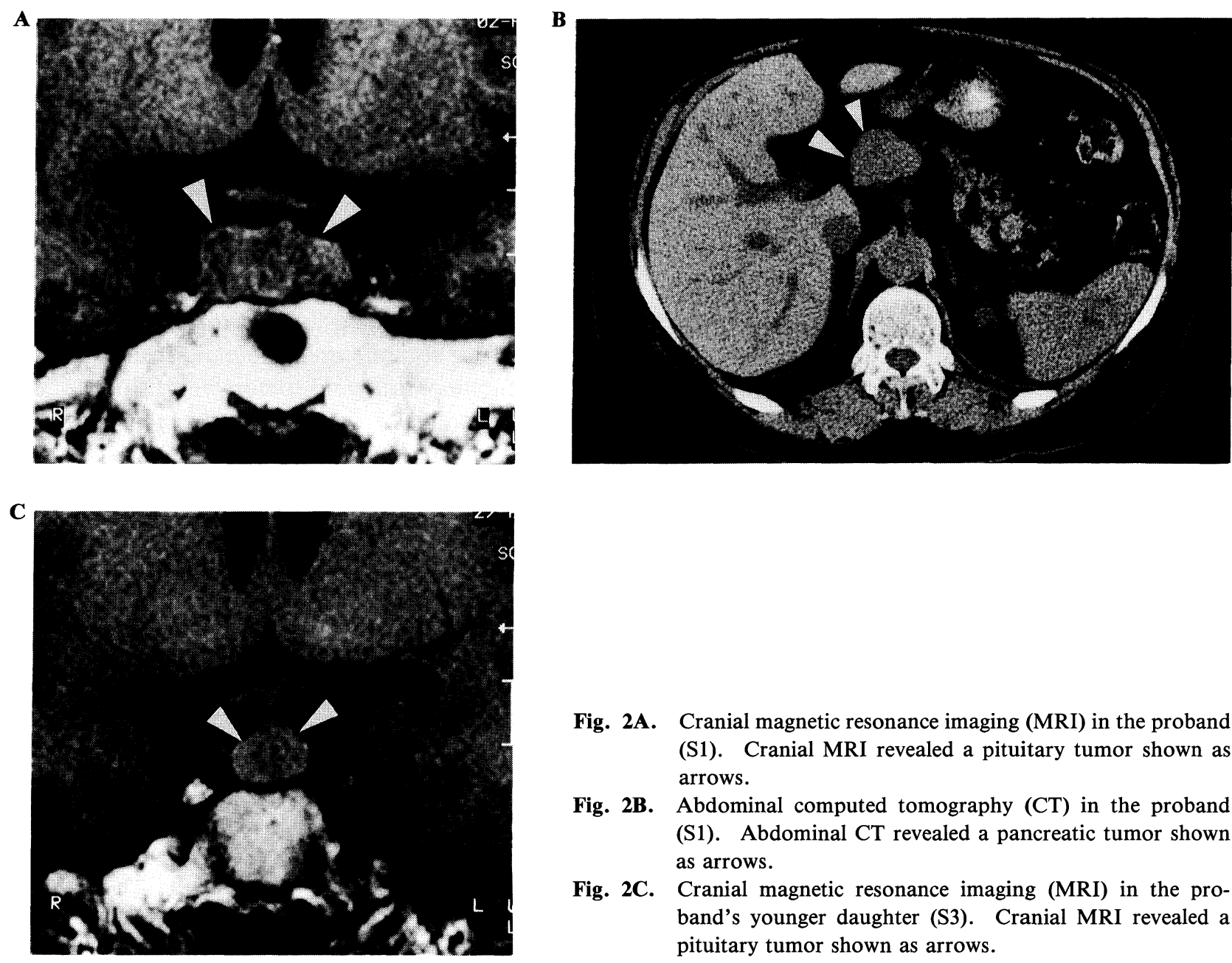

Fig. 2A. Cranial magnetic resonance imaging (MRI) in the proband (S1). Cranial MRI revealed a pituitary tumor shown as arrows.

Fig. 2B. Abdominal computed tomography (CT) in the proband (S1). Abdominal CT revealed a pancreatic tumor shown as arrows.

Fig. 2C. Cranial magnetic resonance imaging (MRI) in the proband's younger daughter (S3). Cranial MRI revealed a pituitary tumor shown as arrows.

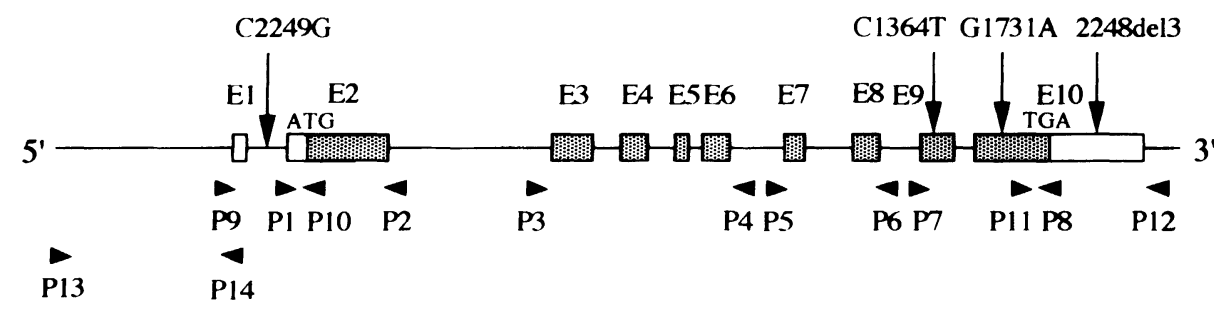

Fig. 3. Simplified map of the MENI gene and location of the primers used in this study. Ten exons (E1-E10) are shown as boxes and the protein coding region is shown as hatched boxes. Primers $(\mathrm{P})$ are indicated with an arrow. P1 to P8 were used for amplification of the open reading frame. P9 to P12 were used for amplification of the $5^{\prime}$ and $3^{\prime}$ untranslated regions. P13 and P14 were used for amplification of the promoter region. The transcription start site, ATG, and stop codon, TGA, are shown in the figure. Four benign polymorphisms are indicated with arrow in the upper section.

plified with PCR in which two pairs of primers (P9P10, P11-P12) were used (Fig. 3). The promoter regions of $1.5 \mathrm{~kb}$ were amplified with PCR with one pair of primers (P13-P14) (Fig. 3). The primer se- quence was 5'-AGGCATGAGCCTGGCATGAACTTGACAC-3' (P13) and 5'-GCGCTGTGGCTTCTGGGATCTCTAGGTCC-3' (P14). The amplified PCR products to be sequenced were electrophoresed 
(a)

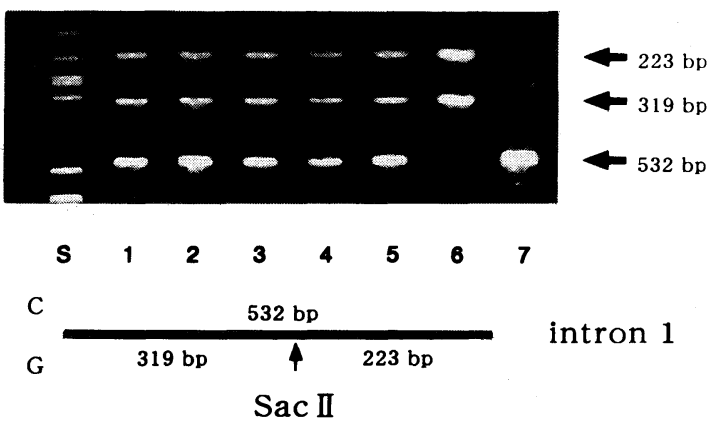

(b)

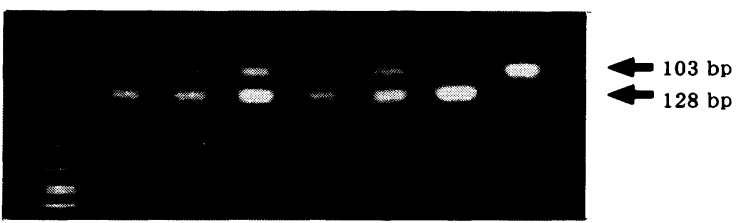

$\mathbf{s}$

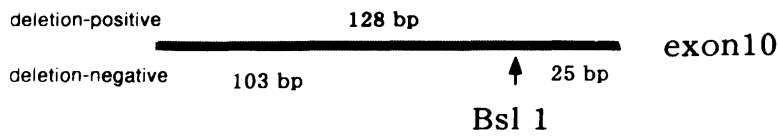

Fig. 4. Results of tissue LOH study. The lane numbers 1-4 are separate parts of the parathyroid tumors obtained from the proband (51 y.o., female) and the number 5 represents her genomic DNA. Lane numbers 6 and 7 are genomic DNA, obtained from normal volunteers, showing homozygous patterns for two benign polymorphisms (C2249G in intron 1 and 2248del3 in exon 10 ), and the standard size marker (S) in the form of $\mathrm{X} 174 / \mathrm{HaeIII}$ digest is indicated. (a) Digestion with Sac II results in two fragments of 223 and $319 \mathrm{bp}$ from the $G$ allele and one fragment of $532 \mathrm{bp}$ from the $C$ allele. Lane numbers 6 and 7 show $G / G$ and $\mathrm{C} / \mathrm{C}$, respectively. (b) Digestion with BslI results in two fragments of 25 and $103 \mathrm{bp}$ from the deletionnegative allele and one band of 128 (125) bp from the deletion-positive allele. Lane numbers 6 and 7 show del $+/+$ and del $-/-$, respectively.

on a 1.5\% agarose gel and purified as previously described [11]. Direct sequencing was performed using a Taq FS Dye Termination Cycle Sequencing Kit (Perkin-Elmer), and automated analysis was done with an ABI 377 sequencer, as previously described [11].

\section{LOH Analysis in Parathyroid Tumors}

Two different polymorphisms (C2249G in intron 1 and 2248del3 in exon 10) in the MENI gene were utilized for detecting $\mathrm{LOH}$ in parathyroid tumors obtained from the proband (Fig. 3). The tumors were frozen at the time of surgery and stored at $-80^{\circ} \mathrm{C}$. Histological evaluation of the parathyroid tumors revealed characteristic features of hyperplasia. Four separate areas were dissected from the four separate parathyroid tumors and DNA was extracted separately from the tissues using a RNA/ DNA Mini Kit (QIAGEN Inc., CA). DNA was amplified with two pairs of primers, as described previously [11], and the PCR products were digested by SacII (Toyobo Co., Osaka, Japan) and BslI (Toyobo) according to the manufacturer's recommendations. The digested sample was electrophoresed on a $1.8 \%$ agarose gel containing $0.5 \mu \mathrm{g} / \mathrm{ml}$ ethidium bromide and photographed. Genomic DNA extracted from the peripheral blood of normal volunteers was used (with informed consent) as controls for the homozygous patterns of each MENI gene polymorphism.

\section{Results}

In genomic DNA extracted from the proband's peripheral blood, no mutation was detected on the entire coding region, exons $2-10$, including the corresponding splice-junction regions of the MENI gene. Neither promoter regions nor the $5^{\prime}$ and $3^{\prime}$ untranslated regions showed mutations. The results of tissue LOH study are shown in Fig. 4. Genomic DNA of the proband's peripheral blood revealed heterozygous patterns $(\mathrm{C} / \mathrm{G}$ and $\mathrm{del}+/-)$ for the two benign polymorphisms (C2249G in intron 1 and 2248del3 in exon 10) (Fig. 4). Homozygous patterns (C/C or G/G and del $+/+$ or del-/-) for each polymorphism examined from normal volunteers are also shown in Fig. 4. All four tissue samples extracted from the proband's parathyroid tumors showed heterozygous patterns similar to the blood samples (Fig. 4). 


\section{Discussion}

Germline mutations of the MEN1 gene appear to be highly associated with the disease carrier in familial MEN1. Two large studies on familial MEN1 have indicated that MEN1 gene mutations were identified in 47/50 [5] and 47/63 [10] of unrelated MEN1 patients, respectively. We have also reported 7 mutations in 8 unrelated Japanese MEN1 patients [11]. In each MEN1 family, a close correlation between $M E N 1$ gene mutation and the carrier of MEN1 was found. We have reported that a germline missense mutation (E45G) was completely in accordance with the onset of MEN1-related lesions in a large Japanese MEN1 family [13]. Germline mutations of the $M E N 1$ gene therefore seem to play an important role in the pathogenesis and tumorigenesis of MEN1. In some cases of familial MEN1, however, MENI gene mutations are not identified [5, $10,11]$. In such cases, it is possible that MENI gene mutations may exist in the promoter regions, on the $5^{\prime}$ and $3^{\prime}$ untranslated regions, since only the open reading frame, including intron-flanking regions, was studied in all of the previous studies. In the present study, no mutation was detected on the entire coding region, promoter regions, and the $5^{\prime}$ and $3^{\prime}$ untranslated regions. A previous study reported a large germline deletion of MEN1 gene which may be missed by PCR-based sequencing [14]. But, the large germline deletion of the MENI gene can be ruled out in our case, because heterozygous polymorphisms of this region were clearly detected by PCR. Nevertheless, a small deletion of one exon and a large inversion cannot be detected by PCR-based sequencing. In addition, mutations in the introns of $M E N 1$ gene cannot be ruled out.

Analysis of the tissues showed no LOH in the parathyroid tumors obtained from the proband in this family. For the detection of $\mathrm{LOH}$, we utilized two benign polymorphisms (C2249G in intron 1 and 2248del3 in exon 10) in the MEN1 gene. Both of these polymorphisms exhibited heterozygous patterns
(C/G for $\mathrm{C} 2249 \mathrm{G}$ and del $+/-$ for 2248del3) in the DNA extracted from peripheral blood. If $\mathrm{LOH}$ occurred in the tumor tissues, the polymorphisms would be hemizygous due to allelic deletions, including the $M E N I$ gene. Here, however, PCR-based $\mathrm{LOH}$ analysis must be carefully considered. The reliability of this method would decrease if a sample of tumor DNA were heavily contaminated by the admixture of normal DNA. We therefore removed four separate sections from the four parathyroid tumors, extracted DNA and used it for PCR independently. All of the results were similar to those in peripheral blood samples, suggesting that $\mathrm{LOH}$ is absent from the parathyroid tumors. However, we do not preclude the possibility that an inactivation of the normal allele without $\mathrm{LOH}$ might have occurred in the tumor tissue.

LOH on chromosome $11 \mathrm{q} 13$ has been reported in $63-100 \%$ of MEN1-associated parathyroid tumors $[3,15,16]$. The Knudson tumor suppressor gene hypothesis states that hereditary cancers develop due to the inheritance of a mutated tumor suppressor gene and that a somatic mutational event involving the wild-type allele of the gene leads to a neoplasm [17]. The high frequency of heterozygous germline mutations of the MENI gene and tissue $\mathrm{LOH}$ reported in many studies appears to be compatible with this hypothesis. In the present case, neither germline mutations of the MENI gene nor tissue LOH were detected, at least by PCR-based methods. Agarwal et al. [5] have reported three mutationnegative kindreds of which one family showed convincing linkage of the MEN1 trait to 11q13. There has been no report indicating that linkage to $11 \mathrm{q} 13$ could be excluded in familial MEN1 except for only one case of atypical MEN1 [18, 19]. Since we had no chance to perform a linkage analysis in the present family, the linkage to $11 \mathrm{q} 13$ cannot be ruled out. Although genetic analysis using PCR-based direct sequencing is very useful as a diagnostic tool for MEN1, we must be aware that mutation-negative cases need to be further investigated.

\section{References}

1. Trump D, Farren B, Wooding C, Pang JT, Besser GM, Buchanan KD, Edwards CR, Heath DA, Jack- son CE, Jansen S, Lips K, Monson JP, O'Halloran D, Sampson J, Shalet SM, Wheeler MH, Zink A, 
Thakker RV (1996) Clinical studies of multiple endocrine neoplasia type 1 (MEN1). $Q J$ Med 89: 653-659.

2. Larsson C, Skogseid B, Oberg K, Nakamura Y, Nordenskjold M (1988) Multiple endocrine neoplasia type 1 gene maps to chromosome 11 and is lost in insulinoma. Nature 332: 85-87.

3. Thakker RV, Bouloux $\mathrm{P}$, Wooding C, Chotai $\mathrm{K}$, Broad PM, Spurr NK, Besser GM, O'Riordan JL (1989) Association of parathyroid tumors in multiple endocrine neoplasia type 1 withloss of alleles on chromosome 11. N Engl J Med 321: 218-224.

4. Chandrasekharappa SC, Guru SC, Manickam P, Olufemi SE, Collins FS, Emmert-Buck MR, Debelenko LV, Zhuang Z, Lubensky IA, Liotta LA, Crabtree JS, Wang Y, Roe BA, Weisemann J, Boguski MS, Agarwal SK, Kester MB, Kim YS, Heppner C, Dong Q, Spiegel AM, Burns AL, Marx SJ (1997) Positionalcloning of the gene for multiple endocrine neoplasia type1. Science 276: 404-407.

5. Agarwal SK, Kester MB, Debelenko LV, Heppner C, Emmert-Buck MR, Skarulis MC, Doppman JL, Kim YS, Lubensky IA, Zhuang Z, Green JS, Guru SC, Manickam P, Olufemi SE, Liotta LA, Chandrasekharappa SC, Collins FS, Spiegel AM, Burns AL, Marx SJ (1997) Germline mutations of the MEN1 gene in familial multiple endocrine neoplasia type 1 and related states. Hum Mol Genet 6: 1169-1175.

6. Lemmens I, Van de Ven WJ, Kas K, Zhang CX, Giraud S, Wautot V, Buisson N, De Witte K, Salandre J, Lenoir G, Pugeat M, Calender A, Parente F, Quincey D, Gaudray P, De Wit MJ, Lips CJ, Hoppener JW, Khodaei S, Grant AL, Weber G, Kytola S, Teh BT, Farnebo F, Thakker RV (1997) Identification of themultiple endocrine neoplasia type 1 (MEN1) gene. Hum Mol Genet 6: 1177-1183.

7. Mayr B, Apenberg S, Rothamel T, von zur Muhlen A, Brabant G (1997) Menin mutations inpatients with multiple endocrine neoplasia type 1. Eur JEndocrinol 137: 684-687.

8. Giraud S, Choplin H, Teh BT, Lespinasse J, Jouvet A, Labat-Moleur F, Lenoir G, Hamon B, Hamon P, Calender A (1997) A large multiple endocrineneoplasia type 1 family with clinical expression suggestive ofanticipation. J Clin Endocrinol Metab 82: 34873492.

9. Shimizu S, Tsukada T, Futami H, Ui K, Kameya T, Kawanaka M, Uchiyama S, Aoki A, Yasuda H, Kawano S, Ito Y, Kanbe M, Obara T, Yamaguchi K. (1997) Germline mutations of theMEN1 gene in Japanese kindred with multiple endocrine neoplasiatype 1. Jpn J Cancer Res 88: 1029-1032.
10. Bassett JH, Forbes SA, Pannett AA, Lloyd SE, Christie PT, Wooding C, Harding B, Besser GM, Edwards CR, Monson JP, Sampson J, Wass JA, Wheeler MH, Thakker RV.(1998) Characterization of mutations in patients with multiple endocrine neoplasia type 1. Am J Hum Genet 62: 232-244.

11. Sato M, Matsubara S, Miyauchi A, Ohye H, Imachi H, Murao K, Takahara J (1998) Identification of fivenovel germline mutations of the MEN1 gene in Japanese multipleendocrine neoplasia type 1 (MEN1) families. J Med Genet 35: 915-919.

12. Mulligan LM, Kwok JB, Healey CS, Elsdon MJ, Eng C, Gardner E, Love DR, Mole SE, Moore JK, Papi L (1993) Germ-line Mutations of the RET protooncogene in multiple endocrine neoplasia type $2 \mathrm{~A}$. Nature 363: 458-460.

13. Miyauchi A, Sato M, Matubara S, Ohye H, Kihara M, Matsusaka K, Nishitani A, Takahara J (1998) A family of MEN1 with anovel germline missense mutation and benign polymorphisms.Endocr $J$ 45: 753-759.

14. Kishi M, Tsukada T, Shimizu S, Futami H, Ito Y, Kanbe M, Obara T, Yamaguchi K (1998) A large germline deletionof the MEN1 gene in a family with multiple endocrine neoplasiatype 1. Jpn J Cancer Res 89: 1-5.

15. Friedman E, De Marco L, Gejman PV, Norton JA, Bale AE, Aurbach GD, Spiegel AM, Marx SJ (1992) Allelic loss fromchromosome 11 in parathyroid tumors. Cancer Res 52: 6804-6809.

16. Lubensky IA, Debelenko LV, Zhuang Z, EmmertBuck MR, Dong Q, Chandrasekharappa S, Guru SC, Manickam P, Olufemi SE, Marx SJ, Spiegel AM, Collins FS, Liotta LA (1996) Allelic deletions on chromosome 11q13 in multiple tumors from individual MEN1 patients. Cancer Res 56: 5272-5278.

17. Knudson AG (1985) Hereditary cancer, oncogenes, and antioncogenes. Cancer Res 45: 1437-1443.

18. Larsson C, Calender A, Grimmond S, Giraud S, Hayward NK, Teh B, Famebo F (1995) Molecular tools for presymptomatic testing in multiple endocrine neoplasia type 1. J Intern Med 238: 239-244.

19. Stock JL, Warth MR, Teh BT, Coderre JA, Overdorf JH, Baumann G, Hintz RL, Hartman ML, Seizinger BR, Larsson C, Aronin N (1997) A kindred with a variant of multiple endocrine neoplasia type 1 demonstrating frequent expression of pituitary tumors but not linked to the multiple endocrine neoplasia type 1 locus at chromosome region 11q13. J Clin Endocrinol Metab 82: 486-492. 